\title{
The possibilities and challenges of using industrial rest products on mine waste management in the Arctic
}

\author{
J. Lu ${ }^{1}$, F. Yuan ${ }^{1}$, A. Barabadi ${ }^{1}$, A. H. S. Garmabaki ${ }^{2,3}$ \& F. Zhang ${ }^{4}$ \\ ${ }^{1}$ Department of Engineering and Safety, UiT, \\ The Arctic University of Norway, Norway \\ ${ }^{2}$ Division of Operation and Maintenance Engineering, \\ Luleå University of Technology, Sweden \\ ${ }^{3}$ Department of Mathematics and Computer Science, \\ Islamic Azad University, Nour Branch, Iran \\ ${ }^{4}$ China Environmental Monitoring Center, China
}

\begin{abstract}
Acid Rock Drainage (ARD) generated from oxidation of sulphide-bearing mine waste is one of the main pollution problems associated with mining activities. Dry cover and water cover are normally used methods to prevent the formation of ARD. However, in the Arctic region, the harsh cold climate, the vulnerability of ecosystems and the drastic climate change make the waste management methods different from other non-Arctic regions. This paper reviewed several successful case studies of dry cover and water cover applications with industrial rest products and further discussed the possibilities and challenges of using industrial rest products to manage mine waste in the Arctic region.

Keywords: ARD, rest products, mine waste management, Arctic.
\end{abstract}

\section{Introduction}

The rise in prices for metals and minerals since 2003 has led to increased mineral production in several parts of the world, especially the Arctic regions. The polar mining boom is heating up as climate change makes new areas and sea routes accessible. The extraction of metals and minerals can affect the natural environment to a significant extent both while active and after operations have 
ceased. Large amounts of waste rock and tailings are produced during resource extraction. It is estimated that more than $90 \%$ of the extracted materials will become waste. A feasibility study in Sweden [1] demonstrated that within 10-20 years the planned mines in Norrbotten area will alone produce $100 \mathrm{M}$ tons of tailings per year and almost similar amount of waste rock.

Acid Rock Drainage (ARD) from oxidation of sulphide-bearing mine waste is one of the main pollution problems associated with mining activities. When the sulphide-bearing waste exposes to oxygen and water, it will start to oxidize and form ARD. As far as the oxidation process starts, it can last for hundreds or even thousands of years. ARD has low $\mathrm{pH}$ and high concentrations of $\mathrm{SO}_{4}{ }^{2-}$, heavy metals and metalloids, which may have detrimental effects on the surrounding environments [2]. The leaching of contaminants from waste deposition facilities will significantly degrade the environment, and the contaminants will further transport through the environmental medium to the ecosystem and the human beings living in the area in the long-term [3]. Therefore, such waste has to be carefully disposed to prevent or reduce the oxidation process.

In Arctic regions, the harsh cold climate, the vulnerability of ecosystems and the drastic climate change make the waste management methods different from other non-Arctic regions [4]. Slow mass and energy exchange in ecosystems of high latitudes, makes trophic chains short, and biodiversity low, which causes rapid migration of pollutants through trophic levels and results in fast and severe ecosystem damages [5]. In addition, the low calcium concentrations in the Arctic lakes make organisms more vulnerable to toxins [5], which is a limiting factor for the management of mine waste. The differences between the polar regions and the rest of the world will affect the remediation strategies and approaches to the contaminated site significantly.

ARD from oxidation of sulphide bearing mine waste has to be prevented or treated. To prevent the formation of ARD from mine waste deposition facilities, two commonly used techniques are dry cover and water cover, i.e. to put a layer of solid or water above the mine waste to prevent the infiltration of oxygen or water, and thus prevent the formation of ARD [6]. In recent years, research has been focusing on using alkaline or organic industrial rest products together with water cover or dry cover technique to mitigate the ARD problem. The use of rest products from other industries to mitigate mine waste problem is preferred technique because it can solve two waste problems at the same time. This paper reviewed several successful case studies of water cover and dry cover together with industrial rest products and discussed the possibilities and challenges of using industrial rest products to manage mine waste in the Arctic region.

\section{Methodology}

\subsection{Dry cover}

Dry covers are typically earthen, organic, or synthetic materials placed over mine waste [6]. The primary purpose of placing dry covers over reactive waste material is to minimize ARD and metal-rich leachate production and its transport [6]. 
Through the MEND (Mine Environment Neutral Drainage) program in Canada, a significant amount of information has been generated about the design and use of dry covers for the prevention of sulphide oxidation [7].

Dry cover has been studied extensively in laboratory, pilot and field scale at real mine sites. Dry cover system usually contains a sealing layer with low hydraulic conductivity and high water holding capacity to decrease the oxygen and water intrusion into the waste. A protective layer is applied above the sealing layer to resist root penetration, freeze/thaw effects, drying etc. When functioning as planned, dry covers can slow sulphide oxidation to an acceptable rate (Figure 1).

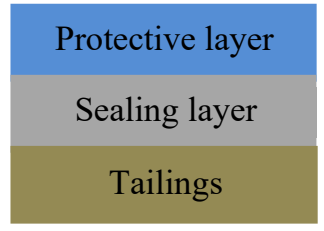

Figure 1: Schematic figure of dry cover application.

In recent years, studies have been focusing on the use of alternative materials such as industrial and municipal waste for mine waste remediation, which could solve two waste problems at the same time. The application of incineration ashes, waste from wood and paper industry and other industries, sewage sludge, steel slag and combinations of these materials for construction of sealing layers and for other applications in mine waste remediation have been investigated [8-10]. Using various types of materials as dry covers on mine waste has been successfully applied at many sites throughout the world $[11,12]$. Several case studies of using industrial rest products such as sewage sludge, green liquor dregs, fly ash, paper mill sludge, steel slag to mitigate mine waste contamination have proved to be successful in laboratory or field scale $[10,13]$.

\subsubsection{Green Liquor Dregs (GLD) from paper mills as dry cover}

Green Liquor Dregs (GLD) is a residual product from sulphate paper mills. GLD has desirable properties to be used as a sealing layer in cover system and maintain its effectiveness in the long term. Table 1 lists the properties of GLD and several successful case studies in laboratory and pilot scale tests.

The long term application potential of GLD is also investigated [9, 17]. The results showed that the GLD's buffering capacity is high and can last for a long time [17]. According to the calculation from leaching experiments, a $30 \mathrm{~cm}$ thick GLD sealing layer with a hydraulic conductivity of $1 \mathrm{E}-08 \mathrm{~m} / \mathrm{s}$ would retain its buffering capabilities for more than 200,000 years [9]. Therefore, GLD is a good cover material that can be used in large scale in the field and effective in the longterm. 
Table 1: $\quad$ Properties of GLD and its applications.

\begin{tabular}{|c|c|c|c|}
\hline $\begin{array}{c}\text { Sealing } \\
\text { layer }\end{array}$ & Desirable properties & Drawbacks & Application \\
\hline GLD & $\begin{array}{ll}\text { - } & \text { Low hydraulic } \\
& \text { conductivity }\left(10^{-8} \text { to }\right. \\
& \left.10^{-9} \mathrm{~m} / \mathrm{s}\right)[14] \\
\text { - } & \text { high water retention } \\
& \text { capacity [14] } \\
\text { - } & \text { small particle size [14] } \\
\text { - } & \text { high neutralization } \\
& \text { potential [14] }\end{array}$ & $\begin{array}{ll}- & \text { Sticky property } \\
& {[14]} \\
- & \text { Insufficient } \\
\text { shear strength } \\
\\
{[14]}\end{array}$ & $\begin{array}{l}\text { Admixtures of GLD } \\
\text { with till, tailings, fly } \\
\text { ash and bark sludge } \\
{[15,16]}\end{array}$ \\
\hline
\end{tabular}

\subsubsection{Fly ash and sludge from paper mills as dry cover}

The potential to use alkaline fly ash from paper mills as a cover material on mine waste is tested in laboratory batch leaching tests and field scale and showed positive results [18]. The efficiency of using fly ash and sludge from paper mills as dry cover over mine tailings was geochemically evaluated at four ten years' old test areas at Garpenberg mine, Sweden [10]. Significant reduction in oxidation rates and leaching of elements from tailings was observed in the profiles with fly ash and sludge cover [10].

\subsubsection{Sewage sludge for mine waste mitigation}

The possibility to use sewage sludge from wastewater treatment for mine waste remediation is investigated in pilot and field-scale at the Kristineberg mine, northern Sweden [19]. The effectiveness of sewage sludge as a sealing layer over sulphide mine waste was evaluated. Data on tailings, leachate water and pore gas geochemistry during eight years from two experimental pilot-scale test cells revealed that the sludge was an effective barrier to oxygen influx [8]. The sulphide oxidation and ARD formation was prevented effectively. The sewage sludge can be effectively utilized as an alternative cover material both as a sealing layer and as a final vegetation substrate within the study periods.

\subsubsection{Fly ash from energy production}

Fly ash is produced from burning of fuels and other materials for energy production. The ash products (fly ash, fluidized bed ash) were excellent buffering materials and had great potential in improving the quality of acidic water. Petrik et al. [20] reported that neutralization of various sources of acid mine water with fly ash or fly ash leachate was possible.

The application of fly ash can attenuate the oxidation of mine waste. The acidity production life of a sulfide-rich mining waste is much higher than the alkalinity production life of any reactive material. The ideal treatment for ARD would suggest the use of techniques that passivate the sulfide surface, and therefore cancel its reactivity [21]. Fly ash can attenuate the oxidation process by forming Fe coatings over pyrite grains at alkaline $\mathrm{pH}$ that impede interaction with oxidizing 
agents [21]. Perez-López et al. [22] examined the processes controlling the oxidation attenuation of a pyritic rich sludge by the buffering capacity of a fly ash using saturated column experiment.

Fly ash can be used as a sealing layer in mine waste mitigation. Formation of hardpan in the contact zone between an alkaline substance and an acid producing waste has been described by many authors (Figure 2) [23]. A hardpan reduces the extent of wind and water erosion at the tailings surface, limiting dust dispersion [24]. Many ash materials have cementitious properties when allowed to react with moderate amount of water [25]. Mixing fly ash with mine waste may result in a reduction of permeability, thus hinder the oxidation of mine waste [26].

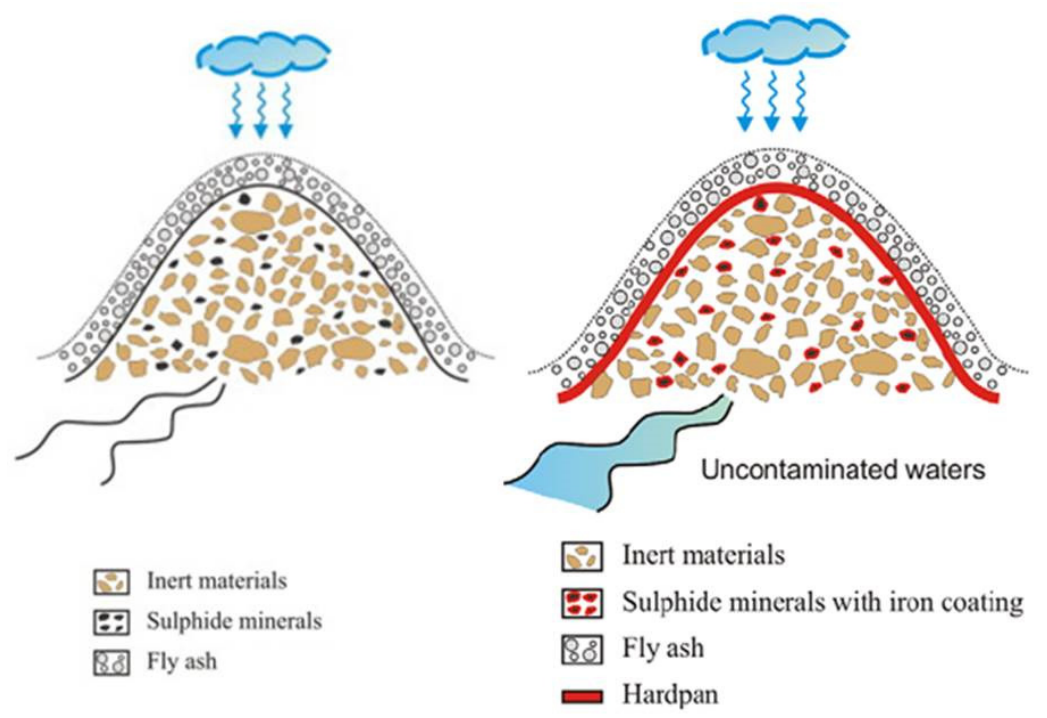

Figure 2: Formation of iron coating and hardpan after fly ash application [23].

\subsection{Water cover}

Concentration of dissolved oxygen in water is significantly lower than that in the atmosphere (approximately 30 times less than in the atmosphere). Disposal of acid generating materials below a water cover is one of the most effective methods for limiting ARD generation [6].

Due to increasing amounts of mine waste generated annually, and the environmental and social issues surrounding disposal on land, mining companies are seeking alternative methods of disposal. Deep-sea mine tailings placement (DSTP) is an alternative to land-based mine-waste disposal options, and is currently practiced by several mines worldwide (http://www.srsl.com/mining/ deep-sea-mine-tailings-placement-dtsp). 
Currently submarine tailings disposal method is only used at five countries. This method is not on the EU's best available technology list. This waste management got a lot of controversial due to its potential impact on the aquaculture and seafood export industry, and tourism around the disposing areas. The mining activity and submarine disposal of mine waste in the Arctic has longterm effects on the ecosystem in the receiving environment. The metal contamination was still detected in seaweeds and blue mussels near the former Black Angel $\mathrm{Pb}-\mathrm{Zn}$ mine in Maarmorilik, West Greenland after two decades of mine closure [27]. Discernible environmental impacts was found up to $10 \mathrm{~km}$ from the tailings discharge point and significant biological effects on blue mussel have been detected in the recipient up to $3 \mathrm{~km}$ from the tailings disposal point in 2015 [28]. Thus, this management method should be fully investigated before its full application.

\subsubsection{Use of rest products in water cover}

To reduce the environmental impact from submarine tailings deposition, a thin layer at the water-tailings interface $(<1 \mathrm{~mm})$ known as the diffusive boundary layer is applied [29]. The application of this thin layer showed to be effective at limiting oxygen diffusion through the tailings in several case studies [30, 31]. Using rest products from other industries as an underwater cover material was investigated in several studies to reduce the negative environmental impact from underwater storage of tailings. The potential suitability of digested sewage sludge as an underwater cover for mine waste tailings, and the degradability of sludge at 20 $22^{\circ} \mathrm{C}$ under flooded anaerobic conditions was evaluated during an incubation time of 230 days [31]. Low biodegradability and low leaching of elements from the sludge was observed [31]. The addition of organic carbon to tailings was investigated to improve the colonization of ecosystem and proved to be effective [32]. Thin-layer caps with activated carbon in Trondheim harbor, Norway were tested at in situ experimental plots and showed high efficiency in reducing the leaching of contaminates into the pore water and thus reduced bioaccumulation of contaminants in marine sediment fauna [33]. The ecosystem effects of thin-layer capping of contaminated sediments were tested in a mesocosm experiment on 9 different capping materials [34]. Thus the application of a thin layer cover above reactive mine tailings could reduce the environmental impact from under water storage of mine waste significantly.

\section{Discussions}

The cold climate in the Arctic region makes environmental management of mine waste different from other regions. At present relatively little research has been conducted relating to contamination issues in cold climates and the unique situations that exist in the Polar Regions. Information gaps exist in this area such as bioaccumulation in polar species, toxicity of contaminants to polar species, migration rates of contaminants through permafrost, and the development of risk assessment models [35]. 
In the Arctic regions, the unique environmental characteristics need to be considered when planning strategies for minimizing ARD [36]. The low temperatures slow most chemical and biological processes and freezing may restrict the migration of pollutants. However depending on the thermal properties of the ground material and local weather conditions, development of an active layer was observed in several studies in the Arctic which promote the transport of oxygen and release and spread of contaminants to the surrounding environment [36]. More work needs to be done in this area regarding contaminant barrier design, cold-climate bioremediation, and transfer of technologies from other areas etc. [35].

In addition, the environmental impacts from climate change in the Nordic region are expected to be more drastic than other regions [37]. Climate change has great impact on the process of contaminant transport and concentrating process in the environment [38]. Changes in global climate and the associated environmental changes in the Nordic region are expected to have significant consequences for contaminant pathways. Over the past 50 years, unprecedented rates of change for both temperature and precipitation have been recorded [39]. Increased temperature will affect chemical reaction kinetics. Any step along the transport and redistribution pathways is influenced by climate change because chemical reactivity, adsorption and accumulation are temperature-dependent. With increased flows there will be changes in stream power and sediment loads with the potential to alter the morphology of rivers and the transfer of sediments to lakes [40]. Climate change is expected to alter environmental distribution of contaminants and their bioaccumulation due to changes in transport, partitioning, and bioaccumulation process [41]. Therefore drastic climate change should be considered when we plan a waste management strategy in the Arctic region.

Industrial rest products have shown promising applications in other regions. Few cover applications in the Arctic have shown positive results [42, 43]. However due to the specific environmental conditions in the region such as the extremely low temperature, low precipitation, freeze-thaw cycles, drastic climate change etc., more research needs to be done to investigate the feasibility of using these rest products in mine waste remediation in the Arctic region.

\section{Conclusions}

Dry cover and water cover were applied above the mine waste to prevent the formation of acid rock drainage (ARD). Industrial rest products such as green liquor dregs (GLD), sewage sludge, fly ash etc. were proved to be successful as a sealing layer above tailings, which significantly reduced the formation of ARD and leaching of contaminants from the waste. Using a thin layer of industrial rest products an underwater cover above mine waste was shown to be efficient in reducing the negative environmental impact from under water storage of mine waste. This waste could potentially be applied in the Arctic region on mine waste management when adjusting the method according to the specific Arctic conditions. 


\section{References}

[1] L. M. Alakangas, C.; Macsik, J.; Nyström, E.; Sandström, N.; AnderssonWikström, A.; Hällström, L. "Mapping of rest products for reclamation and inhibition of mining waste: functional supply and logistics (in Swedish)," 2014.

[2] N. O. O. Egiebor, B. "Acid rock drainage formation and treatment: a review," Asia-pacific journal of chemical engineering, vol. 2, pp. 47-62, 2007.

[3] E. F. da Silva, A. Mlayah, C. Gomes, F. Noronha, A. Charef, C. Sequeira, et al. "Heavy elements in the phosphorite from Kalaat Khasba mine (Northwestern Tunisia): Potential implications on the environment and human health," Journal of Hazardous Materials, vol. 182, pp. 232-245, Oct 15 2010.

[4] G. o. Nunavut, "Engineering challenges for tailings management facilities and associated infrastructure with regard to climate change in Nunavut," Government of Nunavut 2012.

[5] T. I. Moiseenko, A. A. Voinov, V. V. Megorsky, N. A. Gashkina, L. P. Kudriavtseva, O. I. Vandish, et al. "Ecosystem and human health assessment to define environmental management strategies: The case of long-term human impacts on an Arctic lake," Science of the Total Environment, vol. 369, pp. 1-20, Oct 12006.

[6] INAP. (2015). http://www.gardguide.com/index.php?title=Chapter 6 .

[7] A. Cabral, I. Racine, F. Burnotte, and G. Lefebvre, "Diffusion of oxygen through a pulp and paper residue barrier," Canadian Geotechnical Journal, vol. 37, p. 201, 2000.

[8] P. Nason, L. Alakangas, and B. Ohlander, "Using sewage sludge as a sealing layer to remediate sulphidic mine tailings: a pilot-scale experiment, northern Sweden," Environmental Earth Sciences, vol. 70, pp. 3093-3105, Dec 2013.

[9] M. L. Makitalo, J.; Maurice, C.; Ohlander, B. "Prediction of the long-term performance of green liquor dregs as a sealing layer to prevent the formation of acid mine drainage," Journal of Environmental Chemical Engineering, vol. Accepted manuscript, 2015.

[10] J. Lu, L. Alakangas, Y. Jia, and J. Gotthardsson, "Evaluation of the application of dry covers over carbonate-rich sulphide tailings," vol. 244245, pp. 180-194, 2013.

[11] A. Chtaini, A. Bellaloui, G. Ballivy, and S. Narasiah, "Field investigation of controlling acid mine drainage using alkaline paper mill waste," Water Air and Soil Pollution, vol. 125, p. 357, Jan. 2001.

[12] H. K. Karapanagioti and A. S. Atalay, "Laboratory evaluation of ash materials as acid-disturbed land amendments," Global Nest: the Int. J, vol. 3 , p. 11, 2001.

[13] C. Cousins, G. H. Penner, B. Liu, P. Beckett, and G. Spiers, "Organic matter degradation in paper sludge amendments over gold mine tailings," Applied Geochemistry, vol. 24, p. 2293, 122009. 
[14] M. Makitalo, C. Maurice, Y. Jia, and B. Ohlander, "Characterization of Green Liquor Dregs, Potentially Useful for Prevention of the Formation of Acid Rock Drainage," Minerals, vol. 4, pp. 330-344, Jun 2014.

[15] M. S. Mäkitalo, D.; Ikumapayi, F.; Maurice, C.; Öhlander, B. "An Evaluation of Using Various Admixtures of Green Liquor Dregs, a Residual Product, as a Sealing Layer on Reactive Mine Tailings," Mine water and environment, $2015 \mathrm{~b}$.

[16] M. Makitalo, J. Macsik, C. Maurice, and B. Ohlander, "Improving Properties of Sealing Layers Made of Till by Adding Green Liquor Dregs to Reduce Oxidation of Sulfidic Mine Waste," Geotechnical and Geological Engineering, vol. 33, pp. 1047-1054, Aug 2015.

[17] M. Makitalo, J. Lu, N. Stahre, C. Maurice, and B. Öhlander, “Assessment of the effect of aging on Green Liquor Dregs cover for tailings depositsField investigation," 2012.

[18] Y. Jia, C. Maurice, and B. Ohlander, "Effect of the alkaline industrial residues fly ash, green liquor dregs, and lime mud on mine tailings oxidation when used as covering material," Environmental Earth Sciences, vol. 72, pp. 319-334, Jul 2014.

[19] P. Nason, "Field and Pilot-Scale Geochemical Investigations Into Using Sewage Sludge for Sulphidic Mine Waste Remediation," Environmental Geochemistry in the Tropics and Subtropics, Luleå University of Technology, Luleå University of Technology, 2012.

[20] L. F. Petrik, R. A.White, M. J. Klink, V. S.Somerset, C. L.Burgers, and M. V. Fey, "Utilisation of South African fly ash to treat acid coal mine drainage, and production of high quality zeolites from the residual solids," in Proceedings of the 2003 International Ash Utilisation Symposium, 2003.

[21] R. Perez-López, J. Cama, J. M. Nieto, C. Ayora, and M. W. Saaltink, "Attenuation of pyrite oxidation with a fly ash pre-barrier: Reactive transport modelling of column experiments," Applied Geochemistry, vol. 24, p. 1712, Sep 2009.

[22] R. Perez-López, J. M. Nieto, and G. R. de Almodovar, "Utilization of fly ash to improve the quality of the acid mine drainage generated by oxidation of a sulphide-rich mining waste: Column experiments," Chemosphere, vol. 67, p. 1637, 2007.

[23] R. Perez-López, J. M. Nieto, and G. R. de Almodovar, "Immobilization of toxic elements in mine residues derived from mining activities in the Iberian Pyrite Belt (SW Spain): Laboratory experiments," Applied Geochemistry, vol. 22, p. 1919, 2007.

[24] B. G. Lottermoser, Mine Wastes, Characterization, Treatment and Environmental Impacts, Third Edition ed. Berlin Heidelberg, Germany: Springer, 2010.

[25] B. M. Steenari, "Chemical and leaching characteristics of ash from combustion of coal, peat and wood in a 12 MW CFB-a comparative study," Fuel, vol. 78, p. 249, 1999. 
[26] A. Xenidis, E. Mylona, and A. D. Harokopou, "Enhancement of hardpan formation by amending sulphidic tailings with limestone or fly ash," Land Contamination and Reclamation, vol. 15, p. 359, 15 April 20112007.

[27] J. Sondergaard, G. Asmund, P. Johansen, and F. Riget, "Long-term response of an arctic fiord system to lead-zinc mining and submarine disposal of mine waste (Maarmorilik, West Greenland)," Marine Environmental Research, vol. 71, pp. 331-341, Jun. 2011.

[28] S. J. Brooks, C. Harman, M. T. Hultman, and J. A. Berge, "Integrated biomarker assessment of the effects of tailing discharges from an iron ore mine using blue mussels (Mytilus spp.)," Sci Total Environ, vol. 524-525, pp. 104-14, Aug. 152015.

[29] A. S. Awoh, M. Mbonimpa, and B. Bussiere, "Determination of the reaction rate coefficient of sulphide mine tailings deposited under water," Journal of Environmental Management, vol. 128, pp. 1023-1032, Oct. 152013.

[30] L. O. Höglund, R. Herbert, L. Lövgren, B. Öhlander, I. Neretnieks, L. Moreno, et al., "MiMi-Performance Assessment Main Report MiMi 2003:3," 2004.

[31] Y. N. Jia, P., Maurice, C., Alakangas, L., Ohlander, B. "Investigation of biosolids degradation under flooded environments for use in underwater cover designs for mine tailing remediation," Environmental Science and Pollution Research, vol. published online, 2015.

[32] B. T. Haugland, "Faunal Colonization of Submarine Mine Tailings: An Intertidal Experiment to Investigate the Influence of Sediment Organic Carbon Content," Master, Department of Biology University of Bergen, 2014.

[33] G. S. Samuelsson, J. E. Hedman, M. E. Krusa, J. S. Gunnarsson, and G. Cornelissen, "Capping in situ with activated carbon in Trondheim harbor (Norway) reduces bioaccumulation of PCBs and PAHs in marine sediment fauna," Marine Environmental Research, vol. 109, pp. 103-112, Aug 2015.

[34] J. Naslund, G. S. Samuelsson, J. S. Gunnarsson, F. J. A. Nascimento, H. C. Nilsson, G. Cornelissen, et al. "Ecosystem effects of materials proposed for thin-layer capping of contaminated sediments," Marine Ecology Progress Series, vol. 449, pp. 27-U46, 2012.

[35] P. S. Z. Poland, B.A. "Contaminants in the Arctic and the Antarctic: a comparison of sources, impacts, and remediation options," Polar Record, vol. 39, pp. 369-383, 2003.

[36] C. Kyhn and B. Elberling, "Frozen cover actions limiting AMD from mine waste deposited on land in Arctic Canada," Cold Regions Science and Technology, vol. 32, pp. 133-142, Sep. 2001.

[37] M. L. C. Parry, O. F., Palutikof, J. P., van der Linden P. J. and Hanson C. E. "Contribution of Working Group II to the Fourth Assessment Report of the Intergovernmental Panel on Climate Change, 2007," IPCC, Cambridge University Press, Cambridge, United Kingdom and New York, NY, USA.2007.

[38] R. W. M. Macdonald, D.; Li Y.-F. \& Hickie B. "How Will Global Climate Change Affect Risks from Long-Range Transport of Persistent Organic 
Pollutants?" Human and Ecological Risk Assessment: An International Journal, vol. 9, pp. 643-660, 2003.

[39] G. o. Nunavut, "Engineering challenges for tailings management facilities and associated infrastructure with regard to climate change in Nunavut," 2012.

[40] P. G. Whitehead, R. L. Wilby, R. W. Battarbee, M. Kernan, and A. J. Wade, "A review of the potential impacts of climate change on surface water quality," Hydrological Sciences Journal-Journal Des Sciences Hydrologiques, vol. 54, pp. 101-123, Feb 2009.

[41] K. Borga, T. M. Saloranta, and A. Ruus, "Simulating Climate ChangeInduced Alterations in Bioaccumulation of Organic Contaminants in an Arctic Marine Food Web," Environmental Toxicology and Chemistry, vol. 29, pp. 1349-1357, Jun 2010.

[42] P. Nason, "Novel Advances Using Sewage Sludge in Engineered Dry Covers for Sulphide Mine Tailings Remediation," PhD thesis, 2013.

[43] L. J. D. N. Smith, M., Gupton, M., Moore, M., Bailey, B. L., Blowes, D. W., Smith, L., Sego, D. C. "Diavik Waste Rock Project: From the laboratory to the Canadian Arctic," in Securing the Future and 8th ICARD, Skellefteå, Sweden, 2009. 